\title{
Earliest recorded Tatarstan skylark in 2008: non-linear response to temperature suggests advances in arrival dates may accelerate
}

\author{
Oleg V. Askeyev ${ }^{1}$, Tim H. Sparks ${ }^{2, *}$, Igor V. Askeyev ${ }^{1}$ \\ ${ }^{1}$ The Institute of Problems in Ecology and Mineral Wealth, Tatarstan Academy of Sciences, Kazan 420101, A/R - 224, \\ Tatarstan Republic, Russia \\ ${ }^{2}$ NERC Centre for Ecology and Hydrology, Monks Wood, Abbots Ripton, Huntingdon, Cambridgeshire PE28 2LS, UK
}

\begin{abstract}
The return of the skylark Alauda arvensis is a traditional harbinger of spring in Central and Eastern Europe. The record analysed in this study of skylark arrivals in the eastern extremity of Europe is one of the longest extant records of bird migration in the world (131 yr between 1811 and 2008). In the last $30 \mathrm{yr}$ there has been a rapid increase in March temperatures (ca. $3.7^{\circ} \mathrm{C}$ ) and an advance in the arrival date of skylarks $(11 \mathrm{~d}) .2008$ was the earliest year in the whole record. The response of skylark migration to temperature is shown to be non-linear and it is anticipated that advances in arrival dates will now accelerate as temperatures continue to rise.
\end{abstract}

KEY WORDS: Alauda arvensis - Bird migration - Kazan - Phenology - Russia - Tatarstan · Temperature response

Resale or republication not permitted without written consent of the publisher

\section{INTRODUCTION}

The global climate is changing rapidly. The rate of increase in temperature in the northern hemisphere over the second half of the 20th century was the greatest in the past $500 \mathrm{yr}$, and the past decade, in particular, has been the warmest on record (Solomon et al. 2007). These recent climatic changes have impacted on the distribution, ecology and behaviour of animals, particularly on phenology (Rosenzweig et al. 2008).

The timing of when birds return to their breeding area is a key component of studies of the impact of climate change upon bird populations (reviews in Sparks et al. 2003, Lehikoinen et al. 2004, Sokolov 2006, Rubolini et al. 2007). To date, most studies have focused on Western Europe or North America (review in Lehikoinen et al. 2004) with little information on phenological change, if any, in other parts of the globe. Under rising temperatures, earlier arrival of migrants is desirable so that high productivity is maintained in early nesting individuals and synchrony is maintained with the advancing phenology of invertebrates and plants lower in the food web.
In Central and Western Europe there has been evidence of a trend towards earlier spring arrival of migrant birds and this process is likely to continue under climate warming (e.g. Sokolov et al. 1998, Ahas 1999, Loxton \& Sparks 1999, Sueur \& Triplet 2001, Tryjanowski et al. 2002, Sparks et al. 2005, Gordo \& Sanz 2006, Gordo 2007). The skylark Alauda arvensis is migratory in Eastern and Northern Europe, but resident in areas with milder winters (such as the UK). In the study area, and elsewhere, skylarks are present in summer as a very common bird species; numerous in all types of farmland (Askeyev \& Askeyev 1999) and very easy to observe. Tatarstan skylarks overwinter in a wide geographic area from Spain through to Iran. The exact wintering location is likely to be weather dependent; in recent mild winters some birds have even overwintered in southern Russia.

The return of the skylark is a traditional harbinger of spring in Northern, Central and Eastern Europe (Grischenko 1998, Barrett 2002, Hubalek 2004, Vähätalo et al. 2004, Ahas \& Aasa 2006). In these colder parts of its range it is a short-distance (intra-continental) migrant 
and its return in spring is keenly anticipated. In Western Europe it is resident all year and it has less cultural importance. The tradition of observing the arrival of migrant birds in spring has been practised in Europe for over 300 yr (Sparks \& Carey 1995, Lehikoinen et al. 2004). Phenological observations in the eastern extremity of Europe also have a tradition of over $200 \mathrm{yr}$. The first observations of arrival data of the skylark and other bird species in this area were carried out by the famous Russian naturalist and writer S. T. Aksakov. Data on phenological observations were published in a book (Aksakov 1855) and reprinted several times in the 20th century.

Our interest in the migration phenology of the skylark was prompted by the longevity of migration timing data from the Kazan region. In this part of Europe, arrival dates, and phenology in general, are later than in much of the remainder of Europe as a consequence of the harsh winter climate. In this paper we examine the arrival dates of skylark in one of the longest extant records of bird migration in the world.

\section{DATA AND METHODS}

Observations were carried out in the Volga-Kama region of the Tatarstan Republic of Russia. This region covers a large area centred on the city of Kazan $\left(55^{\circ} 45^{\prime} \mathrm{N}, 49^{\circ} 08^{\prime} \mathrm{E}\right)$ and includes various habitats (subtaiga coniferous-deciduous mixed forests, foreststeppe landscape, farmland, rivers, lakes, and towns and villages). The relief is mostly flat or undulating lowland (55 to $380 \mathrm{~m}$ above sea level). The continental climate of the region is typical of Eastern Europe. The average annual temperature is ca. 2 to $4^{\circ} \mathrm{C}$ and monthly mean temperatures range from $-12.1^{\circ} \mathrm{C}$ in January to $19.4^{\circ} \mathrm{C}$ in July. The lowest temperature recorded in our study period was $-52^{\circ} \mathrm{C}$, and the maximum $39^{\circ} \mathrm{C}$. Average annual precipitation is ca. 460 to $530 \mathrm{~mm}$ and snow cover lies for 141 to $164 \mathrm{~d}$.

First observations of the return of the skylark in the Tatarstan Republic and the surrounding territories of the Volga-Kama region in Russia are one of the longest extant records of bird migration in the world. Records of first arrival dates were extracted between 1811 and 2008 from published sources and from the archives of the Institute of Problems in Ecology and Mineral Wealth (IPEMW). Data are not complete over this period; information on skylark first arrival is available for $131 \mathrm{yr}$. Aksakov undertook investigations from 1811 to 1821 in his village, $45 \mathrm{~km}$ north of the town of Buguruslan, and continued from 1822 to 1826 in the village of Aksakovo, $10 \mathrm{~km}$ north of the town of Belebey (both locations ca. $300 \mathrm{~km}$ southeast of Kazan; Aksakov 1855). The next naturalist to make phenolog- ical observations was G. J. Vizgin from 1852 until 1858 in the town of Kozmodemjansk (ca. $150 \mathrm{~km}$ west of Kazan; Ryabinsky 1889). All these sites are within the Volga-Kama region and are climatically and environmentally similar to Kazan (A. V. Popov 1960, V. A. Popov 1978). Subsequent phenological records of skylark first arrival were made close to Kazan, the capital of the Tatarstan Republic. From 1863 to 1869 and 1886 to 1892 first arrivals were recorded by celebrated Russian ornithologists of the Kazan scientific school (Bogdanov 1871, Ruzski 1893). Data on first arrival dates for 1905 to 1952 and 1967 to 1976 were extracted from published sources (Popov et al. 1954, A. V. Popov 1960, V. A. Popov 1978), and other data up to 1980 were obtained from the archive of IPEMW in Kazan. Annual observations from 1981 to 2008 were recorded mainly by authors of this paper (O.V.A. or I.V.A.) at near constant recorder effort. No information is available on either recorder effort over the entire period or on skylark population size, although the latter is thought to have been relatively stable (Askeyev \& Askeyev 1999). Monthly air temperature data for the period from 1812 to 2008 were obtained from the Kazan University meteorological station. Trends through time and relationships with mean monthly temperatures were calculated using regression methods in the MINITAB 15 statistical package (www.minitab.com). Regression coefficients are presented with their SEs. A 'broken stick' (or segmented lines) model between first arrival date and temperature (see 'Results') was fitted using regression methods (Draper \& Smith 1981).

\section{RESULTS}

Regression of skylark first arrival date on year over the entire record revealed a significant advance $(-0.024 \pm$ $0.010 \mathrm{~d} \mathrm{yr}^{-1}, F_{1,129}=5.91, \mathrm{R}^{2}=4.4 \%, \mathrm{p}=0.016$, Fig. 1 ), but the change was much more rapid in the past $30 \mathrm{yr}$ $\left(-0.368 \pm 0.121 \mathrm{~d} \mathrm{yr}^{-1}, F_{1,28}=9.15, \mathrm{R}^{2}=24.6 \%, \mathrm{p}=0.005\right)$. The latter equates to advanced first arrival by $11 \mathrm{~d}$ over the last 3 decades. The first arrival date in 2008 of March 15 was the earliest in the entire record, $4 \mathrm{~d}$ earlier than the next earliest observation in 2002.

All but 2 of 187 available years of mean March air temperature for Kazan have been below freezing (mean $-6.1^{\circ} \mathrm{C}$ ). The 2 supra-zero years were 2002 and 2008. March temperatures have risen over the study period $\left(0.014 \pm 0.004^{\circ} \mathrm{C} \mathrm{yr}^{-1}, F_{1,185}=15.34, \mathrm{R}^{2}=7.7 \%\right.$ ， $\mathrm{p}<0.001$, Fig. 2) and increases have been more pronounced in the last $30 \mathrm{yr}\left(0.123 \pm 0.044^{\circ} \mathrm{C} \mathrm{yr}^{-1}, F_{1,28}=\right.$ $7.83, \mathrm{R}^{2}=21.9 \%, \mathrm{p}=0.009$ ) equating to a temperature rise of $3.7^{\circ} \mathrm{C}$ in the last 3 decades.

Regressing first arrival dates on March mean air temperature suggests a significant relationship $(-1.1 \pm$ 


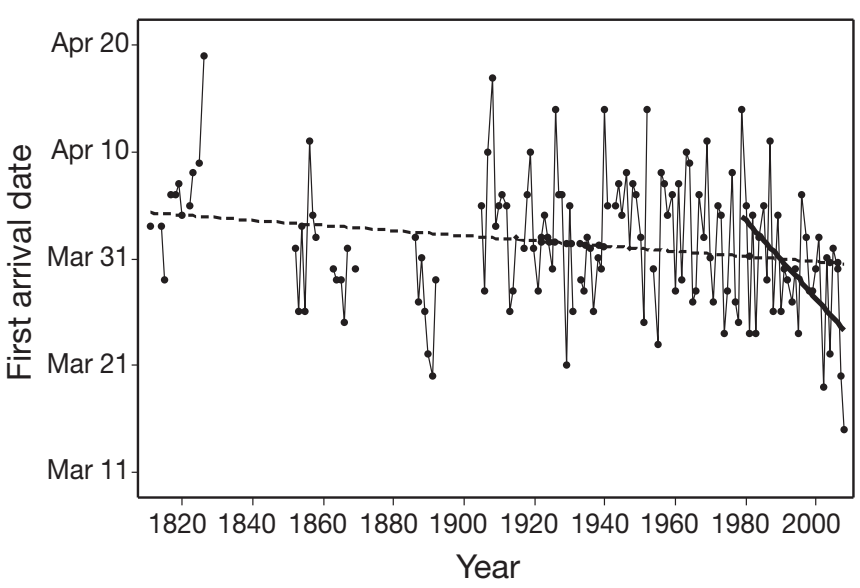

Fig. 1. Alauda arvensis. First arrival dates of skylark in the Tatarstan Republic from 1811 to 2008. Dotted line: regression for entire period; solid line: regression for 1979 to 2008

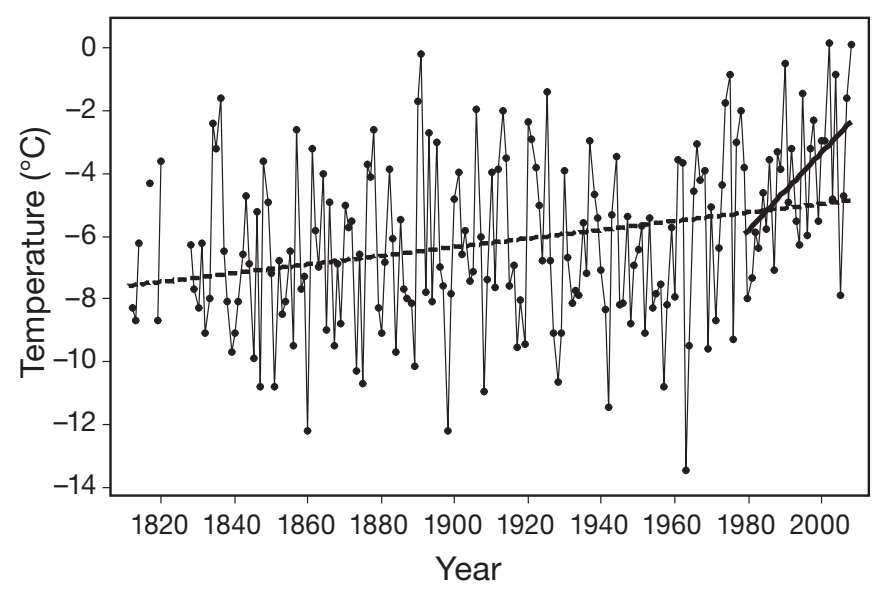

Fig. 2. Mean March air temperature in Kazan from 1812 to 2008. Dotted line: regression for entire period; solid line: regression for 1979 to 2008

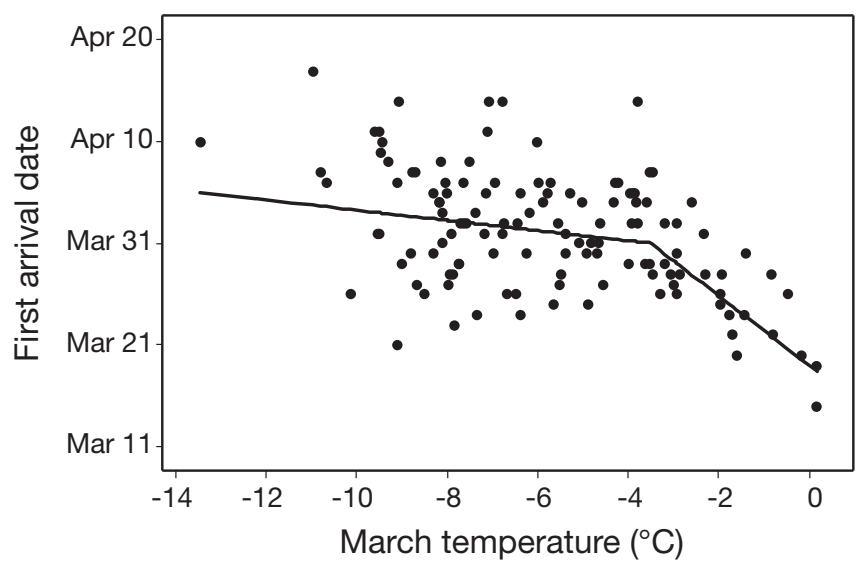

Fig. 3. Alauda arvensis. Relationship between skylark first observation date and mean March air temperature, 'broken stick' line superimposed $\left.0.2 \mathrm{~d}^{\circ} \mathrm{C}^{-1}, F_{1,122}=38.16, \mathrm{R}^{2}=23.8 \%, \mathrm{p}<0.001\right)$. However, it appears that this relationship is more complex than a simple linear relationship; a 'broken stick' model with a break at $-3.5^{\circ} \mathrm{C}$ (selected by iterative optimisation [maximising $\mathrm{R}^{2}$ ] in $0.5^{\circ} \mathrm{C}$ steps) is a significantly better fit (improvement $F_{1,121}=14.31, \mathrm{p}<0.001$; overall model $F_{2,121}=28.32, \mathrm{R}^{2}=31.9 \%, \mathrm{p}<0.001$ ， Fig. 3). This suggests that the relationship with temperature of $-0.5 \pm 0.2 \mathrm{~d}^{\circ} \mathrm{C}^{-1}$ below $-3.5^{\circ} \mathrm{C}$ increases to $-3.4 \pm 0.8 \mathrm{~d}^{\circ} \mathrm{C}^{-1}$ above $-3.5^{\circ} \mathrm{C}$.

\section{DISCUSSION}

With March temperatures increasing rapidly (6 of the last 10 years have been above $-3.5^{\circ} \mathrm{C}$ ) further advances in skylark first arrival in the Tatarstan Republic of Russia are anticipated. The nonlinear nature of the relationship between first arrival and temperature (Fig. 3) suggests that above a critical temperature threshold a much more rapid change in first arrival date will occur. This finding may be an indication that warming in colder climates has little impact on phenology until temperatures approach zero. If this is the case, then unit changes in temperature may affect wildlife in very different ways depending on the local ambient climate. As critical temperature thresholds are passed, changes in phenology may become rapid. In the case of skylark in Tatarstan, however, temperatures of winter months would have to rise substantially for the species to change its status from migrant to winter resident.

In this paper we have used first arrival dates which may be influenced by external factors (Tryjanowski et al. 2005). For example, an increase in either bird numbers or recorder effort may result in earlier sighting based on probabilistic grounds. We do not have complete information on either of these 2 factors for this series of data. However, the skylark is abundant and the population size considered to be stable in this region (Askeyev \& Askeyev 1999). Furthermore, the species is so easily recognizable that we do not think that its first arrival dates will be as influenced by numbers/effort as in more secretive species. The sheer length of the series allows us to examine for non-linearity that may not be obvious in shorter series due to limited statistical power and/or a reduced range of climatic conditions.

The skylark's widespread distribution provides an opportunity for very interesting international research to investigate similarities or dissimilarities in populations across the whole of Europe. We hope that, in due course, it will be possible to combine and analyse skylark phenology from many countries.

Documented changes in bird migration timing in the Northern Hemisphere have been dominated by ad- 
vanced arrivals, particularly in Europe (e.g. Peñuelas et al. 2002, Lehikoinen et al. 2004). This may be less true for colder areas of the globe (e.g. Rubolini et al. 2007, Sokolov \& Gordienko 2008) where winter temperatures may be sub-zero for many months and where global warming has not raised temperatures above freezing point. However, the major changes in temperature found within Russia (for example the $3.7^{\circ} \mathrm{C}$ increase in March temperature reported here) are much greater than on the opposite, oceanic, extreme of Europe, and phenological change may be anticipated as temperatures rise above critical thresholds for activity. The year 2008 had the earliest arrival of skylark in what is one of the longest extant records of bird phenology in the world. Indications are, at this stage, that the spring of 2008 was one of the earliest on record in this region of Russia.

Acknowledgements. We thank V. G. Ilviev and all those who recorded skylark arrival over the past 2 centuries.

\section{LITERATURE CITED}

Ahas R (1999) Long-term phyto-, ornitho- and ichthyophenological time-series analyses in Estonia. Int $\mathrm{J}$ Biometeorol 42:119-123

Ahas R, Aasa A (2006) The effects of climate change on the phenology of selected Estonian plant, bird and fish populations. Int J Biometeorol 51:17-26

Aksakov ST (1855) Hunter's tales and hunt reminiscences about different hunts. Arrival of game and other birds in the Orenburg province. Moscow (in Russian)

Askeyev IV, Askeyev OV (1999) Birds of the Tatarstan Republic. Akademia Nauk Tatarstana, Kazan (in Russian)

Barrett RT (2002) The phenology of spring bird migration to north Norway. Bird Study 49:270-277

Bogdanov MN (1871) Birds and mammals in the blacksoil zone of the Volga region and in the valleys of the Middle and Lower Volga river. Kazan (in Russian)

Draper NR, Smith H (1981) Applied regression analysis. Wiley, New York

Gordo O (2007) Why are bird migration dates shifting? A review of weather and climate effects on avian migratory phenology. Clim Res 35:37-58

Gordo O, Sanz JJ (2006) Climate change and bird phenology: a long-term study in the Iberian Peninsula. Glob Change Biol 12:1993-2004

Grischenko VN (1998) Arrival data changes of some bird species in Kanev reserve in last 30 years. Zapovidna Sprava v Ukraini 4:48-51 (in Ukrainian)

Hubalek Z (2004) Global weather variability affects avian phenology: long-term analysis, 1881-2001. Folia Zool (Brno) 53:227-236

Lehikoinen E, Sparks TH, Zalakevicius M (2004) Arrival and departure dates. Adv Ecol Res 35:1-31

Loxton RG, Sparks TH (1999) Arrival of spring migrants at Portland, Skokholm, Bardsey and Calf of Man. Bardsey Observatory Report 42:105-143

> Peñuelas J, Filella I, Comas P (2002) Changed plant and animal life cycles from 1952 to 2000 in the Mediterranean region. Glob Change Biol 8:531-544
Popov AV (1978) An investigation of the role of passage birds biocenoses in coastal habitat life. Timing and periods of coastal habitat developments. p 94-98. Moscow (in Russian)

Popov VA (1960) Questions about the development of phenological investigations in the territory of the Volga-Kama region (Tatarstan Republic and surrounding republics and provinces). Proceedings of phenological meeting, 29 November to 4 December 1957, Leningrad, p 233-237 (in Russian)

Popov VA (ed) (1978) The birds of the Volga-Kama region. Nauka, Moscow (in Russian)

Popov VA, Popov JK, Priezev GP, Kulaeva TM and others (1954) Results of research on animals in the flood zone of the Kuibjushev reservoir. Proceedings of the Kazan branch of the Soviet Union Academy of Sciences 3:7-218 (in Russian)

Rosenzweig C, Karoly D, Vicarelli M, Neofotis P and others (2008) Attributing physical and biological impacts to anthropogenic climate change. Nature 453:353-358

> Rubolini D, Møller AP, Rainio K, Lehikoinen E (2007) Intraspecific consistency and geographic variability in temporal trends of spring migration phenology among European bird species. Clim Res 35:135-146

Ruzski MD (1893) The results of investigations of birds in the Kazan province. Proc Kazan Naturalist Soc 25:1-394 (in Russian)

Ryabinsky KS (1889) The climate of the town of Kozmodemjyansk by G. Y. Vizgin, observations in 1852-1858. Proc Kazan Naturalist Soc 21:1-38 (in Russian)

Sokolov LV (2006) The influence of global warming on timing of migration and breeding of passerine birds in the twentieth century. Russ J Zool 85:317-341 (in Russian)

Sokolov LV, Gordienko NS (2008) Has recent climate warming affected the dates of bird arrival to the Il'men reserve in the southern Urals? Russ J Ecol 39:56-62

Sokolov LV, Markovets MY, Shapoval AP, Morozov YG (1998) Long-term trends in the timing of spring migration of passerines on the Courish spit of the Baltic Sea. Avian Ecol Behav 1:1-21

Solomon S, Qin D, Manning M Chen Z and others (eds) (2007). Climate Change 2007: the physical science basis. Contribution of Working Group I to the Fourth Assessment Report of the Intergovernmental Panel on Climate. Cambridge University Press, Cambridge

- Sparks TH, Carey PD (1995) The responses of species to climate over two centuries: an analysis of the Marsham phenological records, 1736-1947. J Ecol 83:321-329

Sparks TH, Crick HQP, Dunn P, Sokolov LV (2003) Phenology of selected lifeforms: birds. In: Schwartz MD (ed) Phenology: an integrative environmental science. Kluwer, Dordrecht, p 421-436

Sparks TH, Bairlein F, Bojarinova JG, Hüppop O and others (2005) Examining the total arrival distribution of migratory birds. Glob Change Biol 11:22-30

Sueur F, Triplet P (2001) Rechauffement climatique: les passereaux arrivent-ils plus tot au printemps? Avifaune Picardie 11:111-120 (in French)

> Tryjanowski P, Kuźniak S, Sparks T (2002) Earlier arrival of some farmland migrants in western Poland. Ibis 144:62-68

> Tryjanowski P, Kuźniak S, Sparks TH (2005) What affects the magnitude of change in first arrival dates of migrant birds? J Ornithol 146:200-205

> Vähätalo AV, Rainio K, Lehikoinen A, Lehikoinen E (2004) Spring arrival of birds depends on the North Atlantic Oscillation. J Avian Biol 35:210-216

Submitted: July 17, 2008; Accepted: December 29, 2008

Proofs received from author(s): February 8, 2009 